\title{
Detection of Serum Antibodies and Peripheral Blood Mononuclear Cells Response to Escherichia coli Antigens in Humans
}

Lauana Aparecida Santos ${ }^{1}$

https://orcid.org/0000-0002-0380-5037

Julianne Caravita Grisolia ${ }^{2}$

https://orcid.org/0000-0001-7631-5031

Jorge Kleber Chavasco ${ }^{3}$

https://orcid.org/0000-0002-7401-3977

Luiz Felipe Leomil Coelho ${ }^{3}$

https://orcid.org/0000-0003-4289-384X

Luiz Cosme Cotta Malaquias ${ }^{3^{*}}$

https://orcid.org/0000-0002-4920-072X

\begin{abstract}
${ }^{1}$ Federal University of Alfenas, Graduate Program in Pharmaceutical Sciences, Alfenas, Minas Gerais, Brazil; ${ }^{2}$ Federal University of Alfenas, Graduate Program in Applied Health Biosciences, Alfenas, Minas Gerais, Brazil. ${ }^{3}$ Federal University of Alfenas, Department of Microbiology and Immunology, Alfenas, Minas Gerais, Brazil.
\end{abstract}

Editor-in-Chief: Paulo Vitor Farago

Associate Editor: Paulo Vitor Farago

Received: 2020.04.27; Accepted: 2020.12.18.

*Correspondence: luiz.malaquias@unifal-mg.edu.br; Tel.: +55 3537019579 (L.C.C.M.).

\section{HIGHLIGHTS}

- $\lg G$ and $\lg A$ from normal human serum can recognize $E$. coli antigens and LPS.

- $\quad$ The PBMC proliferation assay was induced by E. coli antigens and by LPS.

- Mucosal antigens may induce local and systemic responses.

Abstract: Among the microorganisms that make up the intestinal microbiota, stands out Escherichia coli, which has as main ecological niche, the large human intestine. Its importance stands out in being part of the pioneer's commensal microorganisms on the colonization of the intestinal mucosa and its pathogenic role causing extra and intra intestinal diseases. The aim of the study was to evaluate the antibody production and proliferative response of Peripheral Blood Mononuclear Cells (PBMC) to E. coli antigens. The bacteria were grown on Brain Heart Infusion broth medium at $35^{\circ} \mathrm{C}$ for 72 hours. Pellet bacteria were lysed for one hour at room temperature with an $8 \mathrm{M}$ sodium guanidine solution. After spin and dialysis, the protein antigens were measured in the supernatant by protein assay. The antigens were characterized by polyacrylamide gel electrophoresis and the antigenic profile by western blotting. The presence of specific $\lg G$ and $\lg A$ antibodies were evaluated using thirty normal human sera by an indirect ELISA. The response of PBMC to E. coli antigens was assessed by MTT metabolization. The results demonstrated that the antigens were composed 
of proteins of different sizes and they were recognized by antibodies present in normal human serum. Human sera presented high titers of $\operatorname{IgG}$ and $\lg A$ antibodies to $E$. coli antigens when compared to the results of lipopolysaccharide. We also showed that total E. coli antigens induced PBMC proliferation at different antigen concentrations. Taken together the results suggest that the antigens from $E$. coli can induce local and systemic immune responses.

Keywords: Antibody response; Escherichia coli; Gastrointestinal Microbiota; MTT; PBMC proliferation; Viability.

\section{INTRODUCTION}

The gastrointestinal tract (GIT) is a site of the human body with approximately $200 \mathrm{~m}^{2}$ of the contact surface where the interactions among the intestinal mucosa, the immune system, ingested food, and the microbiota occurs [1]. The balance of this interaction is necessary for the intestinal mucosa to perform functions such as protection against pathogens and nutrient absorption [2].

Colonizing microorganisms of the intestinal microbiota vary along the lumen and the mucosa at the GIT [3]. The microbial compositions of human GIT are distinct and genetically defined by individual characteristics and environment [4]. The mode of birth, age, eating habits, and genetics has an important role for intra and interindividual variability. The intestinal microbiota is able to preserve and promote the welfare and the absence of diseases, by forming a barrier against potentially pathogenic microorganisms and potentiating the immunological resistance [5].

Escherichia coli is a Gram-negative bacterium belonging to the Enterobateriaceae family. It exists in different profiles in nature, ranging from commensal strains, providing symbiotic resistance against pathogenic microorganisms, to pathogenic strains, causing intra and extra-intestinal diseases in human or in animal hosts. Its main ecological niche is the large intestine of humans and other animals, being part of the commensal intestinal microbiota and belonging to the pioneering colonizing microorganisms immediately after birth [6].

The commensal strains of $E$. coli usually do not contain virulence factors. The presence of this colonizing microorganism has the benefit of helping its host in the breakdown of carbon compounds. In addition, it also plays an important role in the immune response, being able to modulate the immune response of the host. Studies performed on germ-free mice using E. coli strains colonizing the GIT demonstrated that they were able to protect the animals against infection by Salmonella typhimurium [7]. In this study we worked with total $E$. coli antigens due to the fact that this microorganism is a pioneer bacterium in the colonization of the intestinal mucosa and may also being an agent that causes intra and extra-intestinal diseases. The objective of this study was to evaluate the in vitro antibody production and peripheral blood mononuclear cells (PBMC) proliferative response to total antigens of Escherichia coli.

\section{MATERIAL AND METHODS}

\section{Preparation of total E. coli antigens}

Total antigens were prepared from the E. coli ATCC 25922 cultures. An inoculum of the bacteria was added in sterile $50 \mathrm{~mL}$ tubes containing Brain Heart Infusion (BHI) broth and incubated at $35^{\circ} \mathrm{C}$ for 72 hours. After this time, the tubes were centrifuged for 20 minutes at $2000 \mathrm{x} \mathrm{g}$ and the bacteria pellet resuspended in sterile $0.9 \%$ sodium chloride solution and washed three times. Next, the bacteria were lysed by adding to the bacterial pellet $8 \mathrm{M}$ sodium guanidine solution, $\mathrm{pH} 8.0$ leaving the solution stirring for sixty minutes at room temperature. Dialysis was then performed in PBS buffer solution, $\mathrm{pH} 7.2$ at $4{ }^{\circ} \mathrm{C}$ for 48 hours on a $12 \mathrm{kDa}$ pore membrane (Sigma-Aldrich), exchanging the PBS solution twice. The obtained dialysate was centrifuged at $13.000 \times \mathrm{g}$ for thirty minutes at $4{ }^{\circ} \mathrm{C}$ and the supernatant collected. To prevent degradation of the antigen, $1 \mathrm{~mL}$ of the enzyme inhibitor pool (Sigma-Aldrich) was added to the supernatant. Protein dosage was determined by the bicinchroninic acid method. Finally, the obtained antigens were characterized by polyacrylamide gel electrophoresis and western blot analysis.

\section{Polyacrylamide gel electrophoresis and western blotting test}

The E. coli antigens were separated using $12 \%$ polyacrylamide gel electrophoresis (SDS-PAGE), and transferred from the gel to the nitrocellulose membrane using Tris-glycine buffer solution (24 mM Tris, 192 $\mathrm{mM}$ glycine and $20 \%$ methanol). The transfer lasted two hours at $400 \mathrm{~mA}$ and $100 \mathrm{~V}$. The membrane was 
then stained using a $0.3 \%$ Ponceau solution to verify that the gel proteins were transferred to the nitrocellulose paper. The membrane was washed with TBS-T buffer $(100 \mathrm{mM}$ Tris- $\mathrm{HCl}, 0.9 \% \mathrm{NaCl}, 0.1 \%$ Tween 20$)$ and blocked with $3 \%$ bovine serum albumin solution (BSA) for two hours at $25^{\circ} \mathrm{C}$ under stirring. After blocking, the membrane was washed with TBS-T solution. The membrane was incubated with a pool of seven normal human sera at a dilution of $1 / 200$ for 12 hours at $4 \stackrel{\circ}{\circ}$. Thereafter, TBS-T washes were performed. After washing, the membrane was incubated with peroxidase-conjugated anti-human IgG antibody (Sigma-Aldrich) at the dilution of $1 / 1000$ for one hour with shaking at $25^{\circ} \mathrm{C}$. After this time, the membrane was washed with TBS-T solution. Diaminobenzidine (Sigma-Aldrich) plus $0.03 \% \mathrm{H}_{2} \mathrm{O}_{2}(30 \mathrm{vol})$ were used to develop the reaction [8].

\section{Obtaining samples of human sera}

Thirty healthy individuals of both sexes, over 18 years of age were selected. Individuals with the use of corticosteroids or antihistamines were excluded from the study. After signing the informed consent form, 5 $\mathrm{mL}$ of venous blood was collected in tubes with clot activator (BD vacuntainer SST II advanced) to obtain the serum and stored at $-20^{\circ} \mathrm{C}$. The study was approved by the Committee of Ethics in Human Research of the Federal University of Alfenas (protocol number 47823315.0.0000.5142).

\section{Detection of serum IgG and IgA antibodies to E. coli antigens and to LPS by an indirect ELISA test}

To detect serum IgG and IgA antibodies against $E$. coli antigens and to lipopolysaccharide (LPS), 96well flat bottom plates (NUNC) were sensitized with $100 \mu \mathrm{L}$ of total $E$. coli antigens and LPS at the concentration of $10 \mu \mathrm{g} / \mathrm{mL}$ in $0.1 \mathrm{M}$ carbonate-bicarbonate buffer $(\mathrm{pH} 9.6)$ overnight at $4{ }^{\circ} \mathrm{C}$. Plates were then washed in PBS-Tween $0.05 \%$ buffer (PBS-T) and blocked with $150 \mu \mathrm{L}$ of $3 \%$ skimmed milk powder in PBST. $100 \mu \mathrm{L}$ of human serum from thirty healthy subjects diluted $1: 80$ was added to the wells and the plates maintained for $1 \mathrm{~h}$ at $37^{\circ} \mathrm{C}$. After incubation and re-washing with PBS-T, $100 \mu \mathrm{L}$ of goat anti-human $\operatorname{lgG}$ peroxidase conjugate (1:8.000 dilution) (Sigma-Aldrich) or goat anti-human IgA peroxidase conjugate (1:2000 dilution) (Sigma-Aldrich) were added. Plates were incubated for $1 \mathrm{~h}$ at $37^{\circ} \mathrm{C}$. After further washing with PBS$\mathrm{T}, 100 \mu \mathrm{L}$ of OPD substrate (Sigma-Aldrich) resuspended in $0.1 \mathrm{M}$ citrate buffer, pH 4.5 plus $40 \mu \mathrm{L}$ of $\mathrm{H}_{2} \mathrm{O}_{2}$ was added to the plates. After 10 minutes, the reaction was stopped adding $30 \mu \mathrm{L}$ of $2 \mathrm{~N} \mathrm{H}_{2} \mathrm{SO}_{4}$ solution. The readings were made at $492 \mathrm{~nm}$ in ELISA reader (Zenith200rt). Sera were tested in duplicates.

\section{Cell proliferation and viability assay using human peripheral blood mononuclear cells (PBMC)}

$10 \mathrm{~mL}$ of heparinized human peripheral blood was collected to obtain PBMC. Blood was stacked on a Ficoll-Hypaque (Amersham) solution in a ratio of 2:1 in $15 \mathrm{~mL}$ tubes. The tubes were then centrifuged at 500 $\mathrm{x} \mathrm{g}$ for 40 minutes at room temperature. The mononuclear cell ring was collected and transferred to $50 \mathrm{~mL}$ tubes. Cells were washed 3 times with $30 \mathrm{~mL}$ of RPMI 1640 medium. The cell pellet was resuspended in 1 $\mathrm{mL}$ of RPMI supplemented with 1.6\% L-glutamine plus antibiotics (1\% penicillin and streptomycin) (SigmaAldrich) and $10 \%$ inactivated fetal bovine serum (Cultilab). Cells were counted in Neubauer's chamber using $10 \%$ Trypan Blue dye. $2 \times 10^{5} \mathrm{PBMC} /$ per well were cultured in sterile, flat bottom 96-well plates (TTP) in duplicate. Plates were incubated for 48 or 72 hours at $37^{\circ} \mathrm{C}$ with $5 \% \mathrm{CO}_{2}$ with different concentrations of $E$. coli antigens or LPS ranging from 0.19 to $25 \mu \mathrm{g} / \mathrm{mL}$. Phytohemagglutinin (Sigma-Aldrich) solution at $1 \mu \mathrm{g} / \mathrm{mL}$ concentration was used as positive control to assess the rate of cell proliferation and as a negative control the cell culture received only culture medium.

To assess the cell viability rate at the end of the culture period, $20 \mu \mathrm{L}$ of MTT ( $5 \mathrm{mg} / \mathrm{mL}$ ) (Sigma-Aldrich) solution in PBS was added to the wells and plates were incubated at $37{ }^{\circ} \mathrm{C}$ for another 4 hours. At the end of this period, the culture medium was withdrawn and $200 \mu \mathrm{L}$ of DMSO was added. Plates were then read in absorbance at $570 \mathrm{~nm}$ in a microplate reader (Zenit) [9].

To assess the effect of LPS from $E$. coli antigen preparation, LPS removal was performed. A sample from the total antigen of $E$. coli or from commercial available LPS from E. coli (Sigma-Aldrich) was incubated with polymyxin $B(1.2 \mathrm{mg} / \mathrm{mL})$ under agitation for 45 minutes at $4{ }^{\circ} \mathrm{C}$. Samples without polymyxin $B$ addition were also used as a control [10].

Cell proliferation index was calculated as $[(A-B) / A]$, where $A$ and $B$ were the absorbance's of the treated and non-treated cells, respectively. The percentage of cell viability was calculated, as $[(A-B) \times 100]$, where $A$ and $\mathrm{B}$ are the absorbance's of the treated and control cells, respectively. 


\section{Statistical analysis}

Statistical analysis of the data was performed using Graph Pad Prism 6.0 software. The parametric data were analyzed by analysis of variance (ANOVA). The ELISA test results were evaluated using the Student ttest. For the cell proliferation results, the statistical analysis was performed using one-way ANOVA, with Bonferroni post-test. The calculation of the ratio was performed from $E / C$, where $E$ is the mean of the optical densities (O.D.) of the experiment and $\mathrm{C}$ is the mean of the O.D. of the cell control. The differences obtained were considered statistically significant when the $p$ value was lower than 0.05 .

\section{RESULTS}

The electrophoretic profile of total E. coli antigens is shown in Figure $1 \mathrm{~A}$. Several bands on the gel corresponding to the extracted proteins ranging from $200 \mathrm{kDa}$ to below $29 \mathrm{kDa}$ were observed. The antigenic profile of the E. coli antigens can be visualized in Figure 1B. A pool of seven human sera was tested using the western blotting technique. It is possible to visualize the weight of these proteins, ranging from above 200 $\mathrm{kDa}$ to below $29 \mathrm{kDa}$. It is found that a larger number of proteins above 200 and between $66 \mathrm{kDa}$ were recognized with greater intensity by human antibodies. It is observed that there were proteins recognition with greater intensity between 200 and $150 \mathrm{kDa}$ when compared with the others. It also demonstrates that several proteins with weight below $29 \mathrm{kDa}$ were recognized with less intensity when compared to those of higher weights.
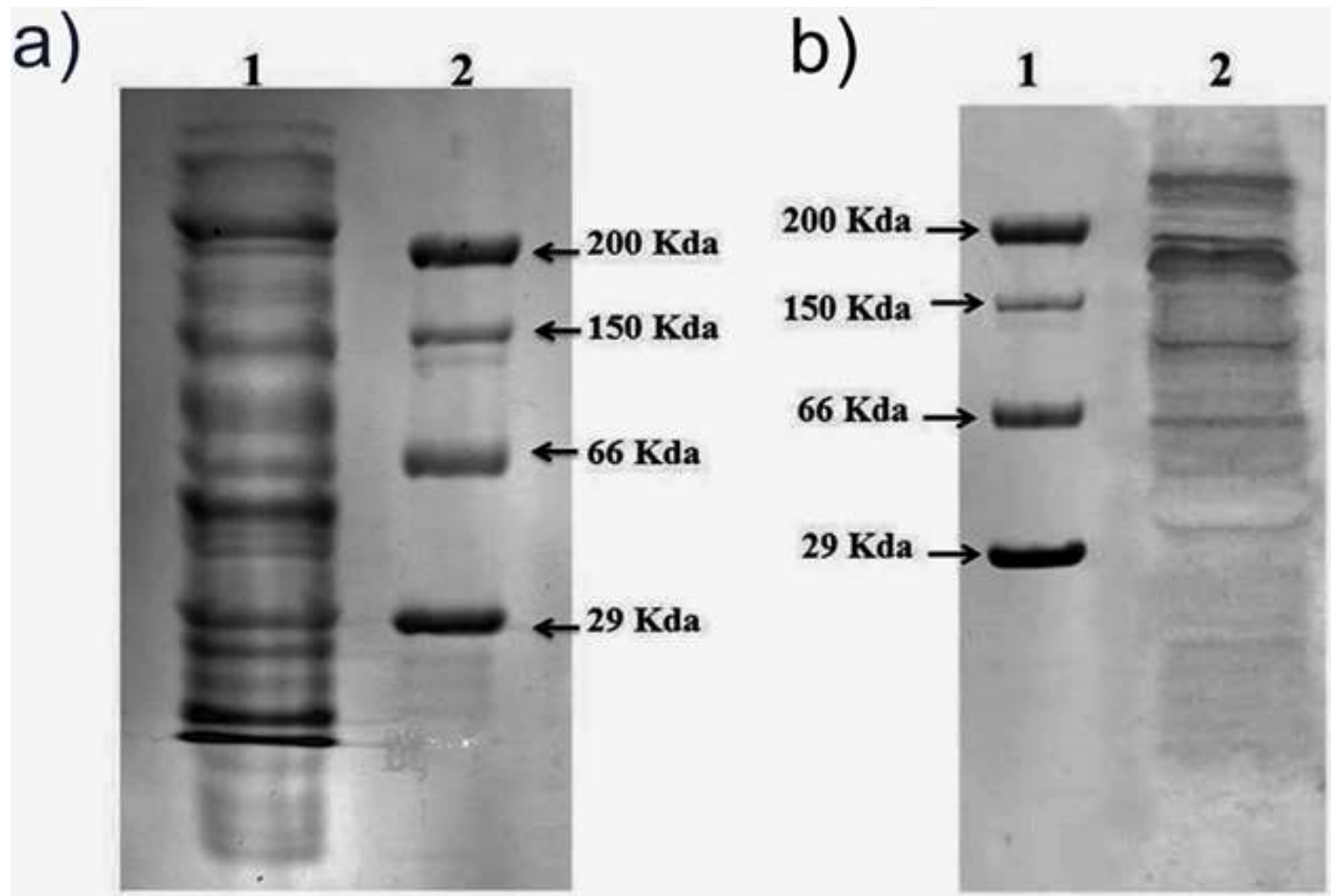

Figure 1. A: Electrophoretic profile by SDS-PAGE. B: Western Blotting Analysis.

A: Lane 1A corresponds to E. coli antigen proteins (strain ATCC 25922) and lane $2 \mathrm{~A}$ is the molecular weight standard $(200,150,66,29 \mathrm{kDa}) .12 \%$ polyacrylamide gel stained with Coomassie blue R-250.

$\mathrm{B}$ : Lane 1B corresponds to the molecular weight standard and lane 2B the E. coli protein profile recognized by a pool of seven normal human sera. The profile of proteins recognized by human sera was revealed using the DAB method.

Samples of human sera $(n=30)$ were used to screen for $\lg G$ antibodies to $E$. coli antigens and LPS (Figure 2A). It can be seen that all samples had significant levels of anti-E. coli lgG antibodies and also for LPS. It is verified that some sera had lower levels of O.D. readings for E. coli antigens and for LPS. It is observed a larger dispersion of O.D. values for LPS as compared to E. coli antigens. The average of O.D. 
for the total E. coli antigen was 3.0 while for LPS it was $1.87(\mathrm{p}<0,001)$. The data suggest that human serum has high titers of $\lg G$ antibodies against $E$. coli antigens when compared to the results found to LPS. In figure $2 \mathrm{~B}$, IgA antibodies screening in human sera $(\mathrm{n}=30)$ against $E$. coli antigens and LPS is shown. It is also noted that all samples show significant levels of serum IgA antibodies to $E$. coli antigens and to LPS. The average of O.D. for the total E. coli antigens was 1.17 while for the LPS it was $0.93(p<0,001)$. It is observed that some sera had higher levels of O.D. for antigenic E. coli extract. From these results, it is possible to infer that human sera presented high titers of $\lg A$ antibodies to $E$. coli antigens when compared to the results of LPS.

a)

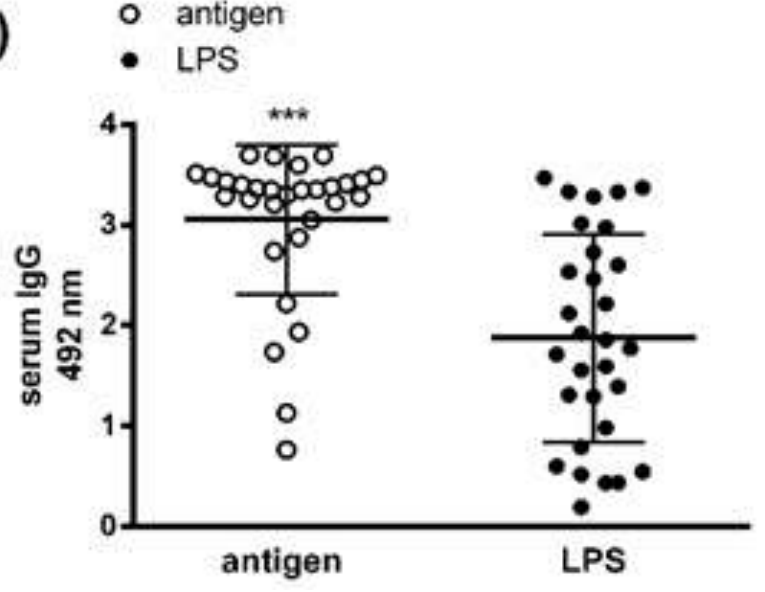

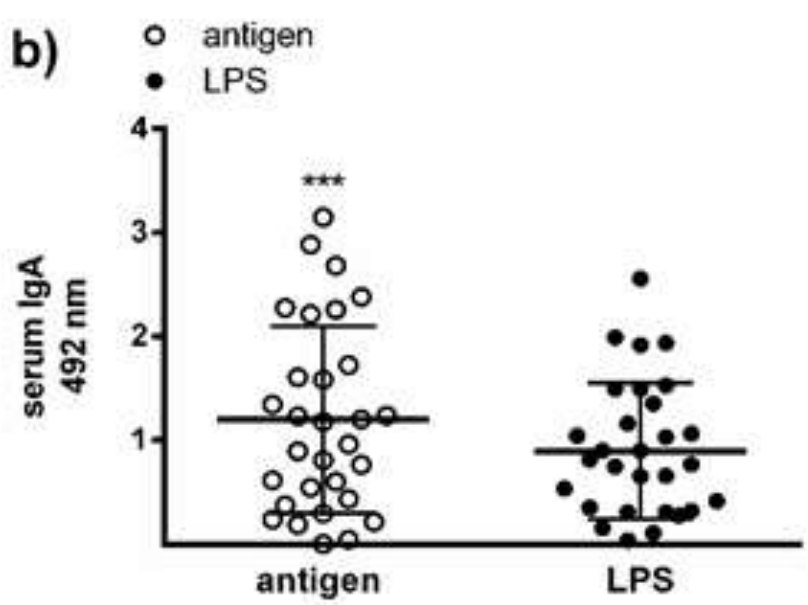

Figure 2. Detection of $\lg G$ and $\lg A$ antibodies in normal human sera. Average of O.D. values at $492 \mathrm{~nm}$ by indirect ELISA test. A: IgG for total E.coli antigen and LPS. B: IgA for total E.coli antigen and LPS. Sera were tested in duplicates $(n=30)$. The statistical analysis was performed using a one-way analysis, followed by Bonferroni post-test.

Figure $3 \mathrm{~A}$ shows PBMC proliferation index during 48 and 72 hours stimulated by different $E$. coli antigen concentrations. Data analysis showed a significant proliferation index (E/C) at 72 hours compared to 48 hours in the antigen concentrations of 25 and $3,12 \mu \mathrm{g} / \mathrm{mL}(p<0,01)$. Since all Gram-negative bacteria have LPS in their cell membrane, it has become necessary to access the effect of LPS present in the antigen preparation on the antigen-induced cell proliferation response. In this way, the antibiotic polymyxin B was used, due to its ability to bind to this molecule and thereafter to reduce its concentration in the antigen extract. Figure 3B shows the proliferation index of PBMC stimulated with the total antigens of $E$. coli antigens or with LPS treated and untreated with polymyxin $B$. It can be seen that the treatment with polymyxin B significantly reduced the PBMC proliferation index induced by the $E$. coli antigens and by LPS $(p<0.01)$. In addition, the cellular viability was also reduced when polymyxin $B$ was added to the antigen or to LPS $(p<0.01)$ (Figure $3 C)$. This result suggests that cell proliferation was stimulated in part by both $E$. coli antigens and LPS. We also investigate the effect of LPS on the PBMC proliferation response and on cellular viability induced by $E$. coli antigens treated with polymyxin $\mathrm{B}$. As can be seen in figure 3D, the treatment of $E$. coli antigen with polymyxin $\mathrm{B}$ did not alter the proliferation response and cell viability (Figure $3 \mathrm{E}$ ). 

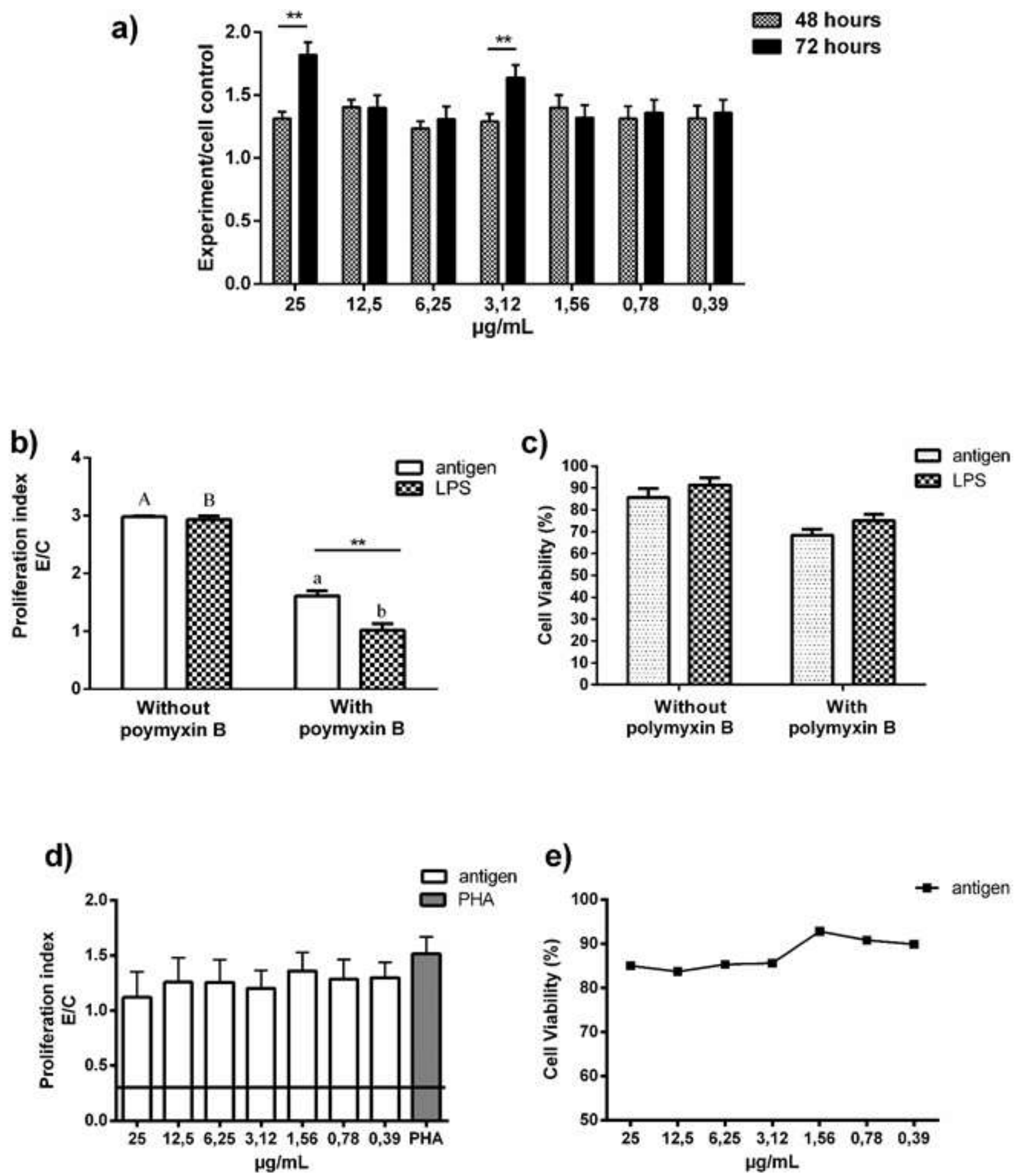

Figure 3. A: PBMC proliferation assay to total de E. coli antigens and to LPS for 48 and $72 \mathrm{~h}$. Total E. coli antigens and LPS concentration $(25 ; 12,5 ; 6,25 ; 3,12 ; 1,56 ; 0,78 ; 0,39 \mu \mathrm{g} / \mathrm{mL})$. B: PBMC Proliferation assay to total $E$. coli antigens and to LPS $(25 \mu \mathrm{g} / \mathrm{mL})$ in the presence or absence of polymyxin $(1.2 \mathrm{mg} / \mathrm{mL}$ for $25 \mathrm{~min})$ for 72 horas. C: PBMC viability to total E. coli antigens and to LPS $(25 \mu \mathrm{g} / \mathrm{mL})$ in the presence or absence of polymyxin B $\left(1.2 \mathrm{mg} / \mathrm{mL}\right.$ for $\left.45 \mathrm{~min}, 4^{\circ} \mathrm{C}\right)$ for 72 horas. D: PBMC proliferation index to total E. coli antigens $(25 \mu \mathrm{g} / \mathrm{mL})$ and PHA $(1 \mu \mathrm{g} / \mathrm{mL})$ treated with polymyxin $\mathrm{B}\left(1.2 \mathrm{mg} / \mathrm{mL}\right.$ for $\left.45 \mathrm{~min}, 4^{\circ} \mathrm{C}\right)$ for 72 horas. The continuous line represents the control of cells without stimulus. $\mathrm{E}$ : PBMC viability to total $E$. coli antigens $(25 ; 12,5 ; 6,25 ; 3,12 ; 1,56 ; 0,78 ; 0,39 \mu \mathrm{g} / \mathrm{mL})$ treated with polymyxin $\mathrm{B}(1.2 \mathrm{mg} / \mathrm{mL}$ for $45 \mathrm{~min}, 4^{\circ} \mathrm{C}$ ) for 72 horas.

PBMC: $2 \times 105$ cells $/$ well. MTT: $5 \mathrm{mg} / \mathrm{mL}$ was added to the cultures 4 horas before the end of the culture period. The formazan crystals were solubilized with the addition of $200 \mu \mathrm{L}$ of DMSO. The absorbance reading was taken at $570 \mathrm{~nm}$. Statistical analysis was performed using a one-way analysis, followed by Bonferroni post-test. 


\section{DISCUSSION}

The gastrointestinal tract is colonized mainly by facultative anaerobic bacteria, especially $E$. coli, since it is one of the pioneer microorganisms in intestinal colonization. Studies indicate that colonization of the intestinal mucosa by commensal bacteria provides many benefits to the host [12]. Commensal bacteria contribute to prevent the growth of pathogenic microorganisms and help in the metabolic function of the host. Currently, studies have been carried out to understand the role and interaction of the intestinal microbiota with the host mucosal immune system [12,13]

The intestinal microbiota resides on the epithelial surfaces of the gastrointestinal tract, which is a large area of bacterial colonization. Associated with this exists a complex network of cells of the immune system. Escherichia coli, a microorganism that is common in the intestinal mucosa of animals and humans, exerts an interaction with the host and promotes homeostasis [14]. The immune response to commensal microorganisms is essential for the maturation of local and systemic lymphoid tissue. Therefore, the intestinal microbiota may have the potential to regulate the immune system at the mucosal level and the host systemic level [15].

This study analyzed the electrophoretic profile the antigen extract from a standard (ATCC) E. coli culture. The extraction process involved rupture of the bacterial cell wall and the bands present in the gel were visualized in Figure 1A. The electrophoretic profile indicated that the antigenic extract was composed of several proteins. The process of extracting proteins using sodium guanidine has as the main advantage of having fewer contaminants in the antigen extract from the bacterial pellet [16]. The same method of extraction was employed with a success to obtain proteins from Pseudomonas sp [17,18].

The western blotting assay shown that normal human sera were able to recognize different $E$. coli antigen proteins. Human sera strongly recognized proteins whose weights were greater than $66 \mathrm{kDa}$ (Figure 1B). Alerasol and coauthors carried out the western blotting assay for the identification of the antigens recognition profile in sera from BALB/C mice immunized with enterotoxigenic $E$. coli [19]. The results demonstrated that mice sera were able to recognize proteins comprising weights ranging from 42 to $29 \mathrm{kDa}$ and $14 \mathrm{kDa}$. These results have shown that the antigen recognition profile for human sera was partially similar, once a repertoire of protein bands comprising the weights below $66 \mathrm{kDa}$ which were also recognized. The presence of reactive serum antibodies to the different bacterial antigens can be interpreted as indicative of previous sensitization. The stimuli induced by $E$. coli antigens may be able to stimulate the production of protective antibodies at both the mucosal and serum levels. Sera from healthy subjects were accessed for the presence of anti-E. coli and anti-LPS antibodies. All tested sera presented significant levels of IgG and IgA antibodies for both $E$. coli antigens and to LPS (Figure 2A and 2B). Such results may suggest a systemic response to those antigens. According to Peterson and coauthors [20], antibodies may exert the function of protection to the intestinal mucosa and mediating the immunological tolerance to the colonizing microorganisms. The results presented by El-Kamary and coauthors demonstrated the presence of significant levels of $\lg$ and $\lg A$ antibodies in human sera after oral immunization with E. coli antigens, reinforcing our results [21]. Snoeck and coauthors emphasizes that secretory $\lg A$ is the first line of defense of the host, although serum $\lg A$ is part of the second line of defense of the organism. Such a function can also be applied to the IgG [22]. The presence of $\lg A$ detected in human serum samples may come from the differentiation of $B$ cells into locally induced IgA-producing cells in the lamina propria of the small intestine. In turn, the presence of IgG may suggest a class switching in antibody-producing cells [20].

LPS is a hallmark of Gram-negative bacteria. The presence of $\lg G$ and $\lg A$ anti-LPS antibodies (Figure $2 \mathrm{~A}$ and $2 \mathrm{~B}$ ) was also investigated. Balabanova and coauthors detected the presence of anti-LPS IgG antibodies from E. coli O104-H4 in human [22]. Luzzi and coauthors point out that there is evidence that antiLPS antibodies are capable of preventing host colonization by pathogenic bacteria, for example E. coli $\mathrm{O} 157$ [11]. In addition, studies have described that one of the similarities among $E$. coli strains is the presence of LPS, as they may have epitopes shared with other $E$. coli and also with other microorganisms, such as other Gram-negative bacteria [4]. Thus, this may explain the results found in the determination of serum antibodies to LPS, since cross-reactivity may occur.

From the cell proliferation assay evaluated by mitochondrial activity, it was observed that the $E$. coli antigen was able to stimulate PBMC. Different antigen concentrations were able to stimulate mononuclear cells proliferation response. The highest mitochondrial activity was found at 72 hours of culture (Figure $3 \mathrm{~A}$ ). The choice of tetrazolium salt in this study to assess the rate of cell proliferation was due to the fact that it offers an accessible and safer option for performing the technique. Besides, this technique can be used to measure cellular activation and cytotoxicity. The colorimetric and radioactive assays showed excellent agreement for Con A stimulations, and showed a small difference between the endpoint of LPS stimulations. 
The main advantages of the colorimetric assay are its rapidity and precision, and the lack of any radioisotope. Furthermore, it was a technique that in this experimental model showed us satisfactory and reproducible results, in addition to being widely used [23]. Zeuthen and coauthors [24] have demonstrated in cell cultures obtained from germ-free animals that the antigens of $L$. acidophilus and $E$. coli are able to induce cell proliferation and the production of anti-inflammatory cytokines. They also observed that LPS may be able to negatively regulate TLR-4 expression and this may allow a tolerance to this molecule to occur in the intestinal mucosa. Carasi and coauthors also evaluated the immune response of Lactobacillus kefir in human PBMC and demonstrated that it was able to induce cell proliferation and IL-6, IL-10, INF- $\gamma$ and GM-CSF production [25]. Finally, they concluded that this microorganism could be a strong candidate to be used in the control of intestinal diseases [26].

As PBMC proliferation were stimulated by the $E$ coli and LPS antigen, we investigated the involvement of LPS in the induction of PBMC proliferation. The results shown in figure $3 \mathrm{~A}$ and $\mathrm{B}$ reveal that the proliferation and the viability of PBMC was not affected by the treatment with polymyxin $B$. The viability of cells treated with polymyxin B remained around $70 \%$ and was slightly lower compared to cells not treated with this antibiotic. This result may suggest that even at low concentration, this drug was able to induce minimal toxicity in these cells, but there is still a significant number of viable cells. Our results may suggest that LPS is not the solely responsible for the activation of these cells. This fact can be verified in Figure 3C in which PBMC were stimulated with less intensity when the antigen was treated with polymyxin B. LPS is an important inducer of a mucosal immune response, but the secreted proteins are also responsible for inducing cellular activation which in turn make the immune cells more metabolically active and thus to induce a protective immune response at the mucosal level. The results presented in figure 3D show the polymyxin $B$ treated antigen was able to stimulate the PBMC even in its smallest concentrations and the viability was not altered either (Figure 3E). Our work shows the ability of human blood cells to be stimulated in vitro by different E. coli antigenic proteins [27].

The commensal Gram-negative bacteria are the main producers of LPS in the intestinal mucosa. Epithelial alkaline phosphatase dephosphorylates bacterial LPS, making it tolerogenic and incapable of stimulating TLR9. In the intestinal epithelium, alkaline phosphatase is concentrated to the apical membrane contributing to induce an inflammatory response or immune tolerance. For this reason, bacterial PAMPs are involved not only in the induction of immune responses but also in the tolerance of the intestinal mucosa [28].

The present study showed that $\lg G$ and $\lg A$ antibodies from normal human serum were able to recognize various proteins from $E$. coli antigens and from LPS. The PBMC proliferation assay was induced by $E$. coli antigens and by LPS, suggesting that mucosal antigens from the microbiota may induce local and systemic responses, indicating a positive association between colonization of the intestinal mucosa and the host defense system.

Funding: This study was financed in part by the Coordenação de Aperfeiçoamento de Pessoal de Nível Superior Brasil (CAPES) - Finance Code 001 (L.A.S.; J.C.G.) and by Fundação de Amparo à Pesquisa no Estado de Minas Gerias - FAPEMIG (CBB - APQ-00461-13) (L.C.C.M.).

Conflicts of Interest: "The authors declare no conflict of interest."

\section{REFERENCES}

1. Viggiano D, laniro G, Vanella G, Bibbò S, Bruno G, Simeone G, et al. Gut barrier in health and disease: focus on childhood. Eur Rev Med Pharmacol Sci. 2015;19:1077-85.

2. Silva MF, Sivieri K, Rossi EA. Effects of a probiotic soy product and physical exercise on formation of pre-neoplastic lesions in rat colons in a short-term model of carcinogenic. J Int Soc Sports Nutr. 2009;6:1-6.

3. De Moraes ACF, Da Silva IT, Almeida-Pititto B de, Ferreira SRG. Microbiota intestinal e risco cardiometabólico: mecanismos e modulação dietética. Arq Bras Endocrinol Metabol [Internet]. 2014;58(4):317-27. Available from: http://www.scielo.br/scielo.php?script=sci_arttext\&pid=S0004-27302014000400317\&lng=pt\&tlng=pt

4. Holscher HD. Dietary fiber and prebiotics and the gastrointestinal microbiota. Gut Microbes. 2017;8(2):172-84.

5. Qadri F, A.-M. S, A.S.G. F, Sack BR. Enterotoxigenic Escherichia coli in Developing Countries: Epidemiology, Microbiology, Clinical Features, Treatment, and Prevention. Clin Microbiol. 2005;18(3):465-83.

6. Bettelheim KA, Goldwater PN. Escherichia coli and sudden infant death syndrome. Front Immunol. 2015;6:1-7.

7. Smith K, McCoy K, Macpherson A. Use of axenic animals in studying the adaptation of mammals to their commensal intestinal microbiota. Semin Immunol. 2007;19(2):59-69. 
8. Towbin $\mathrm{H}$, Staehelin T, Gordon J. Electrophoretic transfer of proteins from polyacrylamide gels to nitrocellulose sheets: procedure and some applications. Proc Natl Acad Sci [Internet]. 1979;76(9):4350-4. Available from: http://www.pnas.org/cgi/doi/10.1073/pnas.76.9.4350

9. De Souza TB, Orlandi M, Coelho LFL, Malaquias LCC, Dias ALT, De Carvalho RR, et al. Synthesis and in vitro evaluation of antifungal and cytotoxic activities of eugenol glycosides. Med Chem Res. 2014;23(1):496-502.

10. Ergin A, Büssow K, Sieper J, Thiel A, Duchmann R, Adam T. Homologous high-throughput expression and purification of highly conserved E coli proteins. Microb Cell Fact. 2007;6:1-12.

11. Luzzi I, Tozzi AE, Rizzoni G, Niccolini A, Benedetti I, Minelli F, et al. Detection of serum antibodies to the lipopolysaccharide of Escherichia coli $\mathrm{O} 103$ in patients with hemolytic-uremic syndrome. J Infect Dis. 1995;171(2):514-5.

12. Brown EM, Sadarangani M, Finlay BB. The role of the immune system in governing host-microbe interactions in the intestine. Nat Immunol. 2013;14(7):660-7.

13. Manuzak J, Dillon S, Wilson C. Differential interleukin-10 (IL-10) and IL-23 production by human blood monocytes and dendritic cells in response to commensal enteric bacteria. Clin Vaccine Immunol. 2012;19(8):1207-17.

14. Jabra-Rizk M, Meiller T, James C, Shirtliff M. Effect of farnesol on Staphylococcus aureus biofilm formation and antimicrobial susceptibility. Antimicrob Agents Chemother. 2006;50(4):1463-9.

15. Palmer I, Wingfield P. Preparation and Extraction of Insoluble (Inclusion-Body) Proteins from Escherichia coli. Curr Protoc Protein. 2012;2-25.

16. Austin JW, Stewart M, Murray RGE. Structural and chemical characterization of the S layer of a Pseudomonas-like bacterium. J Bacteriol. 1990;172(2):808-17.

17. Rodrigues NF, Van Tilburg Bernardes E, Rocha RP, Da Costa LCF, Coutinho ACA, Dos Santos Muniz M, et al. Bovine serum albumin nanoparticle vaccine reduces lung pathology induced by live Pseudomonas aeruginosa infection in mice. Vaccine. 2013;31(44):5062-6.

18. Alerasol M, Gargari SLM, Nazarian S, Bagheri S. Immunogenicity of a fusion protein comprising coli surface antigen 3 and labile B subunit of enterotoxigenic Escherichia coli. Iran Biomed J. 2014;18(4):212-8.

19. Peterson DA, McNulty NP, Guruge JL, Gordon Jl. IgA Response to Symbiotic Bacteria as a Mediator of Gut Homeostasis. Cell Host Microbe. 2007;2(5):328-39.

20. El-Kamary SS, Cohen MB, Bourgeois AL, Van De Verg L, Bauers N, Reymann M, et al. Safety and immunogenicity of a single oral dose of recombinant double mutant heat-labile toxin derived from enterotoxigenic Escherichia coli. Clin Vaccine Immunol. 2013;20(11):1764-70.

21. Snoeck V, Peters IR, Cox E. The IgA system: A comparison of structure and function in different species. Veterinary Research. 2006;37(13):455-67.

22. Balabanova Y, Klar S, Deleré Y, Wilking H, Faber MS, Lassen SG, et al. Serological Evidence of Asymptomatic Infections during Escherichia coli O104:H4 Outbreak in Germany in 2011. PLoS One. 2013;8(9):2011-4.

23. Mosmann T. Rapid colorimetric assay for cellular growth and survival: Application to proliferation and cytotoxicity assays. J Immunol Meth. 1983;65(1-2):55-63.

24. Zeuthen LH, Fink LN, Metzdorff SB, Kristensen MB, Licht TR, Nellemann C, et al. Lactobacillus acidophilus induces a slow but more sustained chemokine and cytokine response in naïve foetal enterocytes compared to commensal Escherichia coli. BMC Immunol. 2010;11.

25. Carasi P, Racedo SM-Jacquot C, Romanin DE, Serradell MA, Urdaci MC. Impact of kefir derived lactobacillus kefiri on the mucosal immune response and gut microbiota. J Immunol Res. 2015;2015:361604.

26. Chichlowski M, Rudolph C. Visceral pain and gastrointestinal microbiome. J Neurogastroenterol Motil. 2015;21(2):172-81.

27. Belkaid $\mathrm{Y}$, Oldenhove $\mathrm{G}$. Tuning microenvironments: induction of regulatory $\mathrm{T}$ cells by dendritic cells. Immunity. 2008;298(3):362-71.

28. Weng M, Walker WA. The role of gut microbiota in programming the immune Phenotype. J Dev Orig Heal Dis. 2013;4(3):1-23.

2021 by the authors. Submitted for possible open access publication under the terms and conditions of the Creative Commons Attribution (CC BY NC) license (https://creativecommons.org/licenses/by-nc/4.0/). 